\begin{tabular}{|l|l|}
\hline “Mineirinho" de Clarice Lispector, una reflexión sobre la violencia & Titulo \\
\hline Hernández Escobar, María Cristina - Autor/a; & Autor(es) \\
\hline $\begin{array}{l}\text { De Raíz Diversa. Revista Especializada en Estudios Latinoamericanos (Vol. 3 no. 5 } \\
\text { ene-jun 2016) }\end{array}$ & En: \\
\hline México D.F. & Lugar \\
\hline $\begin{array}{l}\text { Programa de Posgrado en Estudios Latinoamericanos, Universidad Nacional } \\
\text { Autónoma de México }\end{array}$ & Editorial/Editor \\
\hline 2016 & Fecha \\
\hline $\begin{array}{l}\text { Violencia policial; Delincuencia; Estado; Religión; Autoritarismo; Justicia; Literatura; } \\
\text { Crónica; Ensayo; América Latina; }\end{array}$ & Colección \\
\hline Artículo & Temas \\
\hline $\begin{array}{l}\text { "http://biblioteca.clacso.edu.ar/Mexico/ppel-unam/20160630033123/7_Mineirinho_de_Clarice_Lispector-una_reflexion_sobre_la_violencia } \\
\text { Maria_Cristina_Hernandez_Escobar.pdf" }\end{array}$ & URL \\
\hline $\begin{array}{l}\text { Reconocimiento-No Comercial-Sin Derivadas CC BY-NC-ND } \\
\text { http://creativecommons.org/licenses/by-nc-nd/2.0/deed.es }\end{array}$ & Licencia \\
\hline
\end{tabular}

Segui buscando en la Red de Bibliotecas Virtuales de CLACSO http://biblioteca.clacso.edu.ar

Consejo Latinoamericano de Ciencias Sociales (CLACSO)

Conselho Latino-americano de Ciências Sociais (CLACSO)

Latin American Council of Social Sciences (CLACSO)

www.clacso.edu.ar

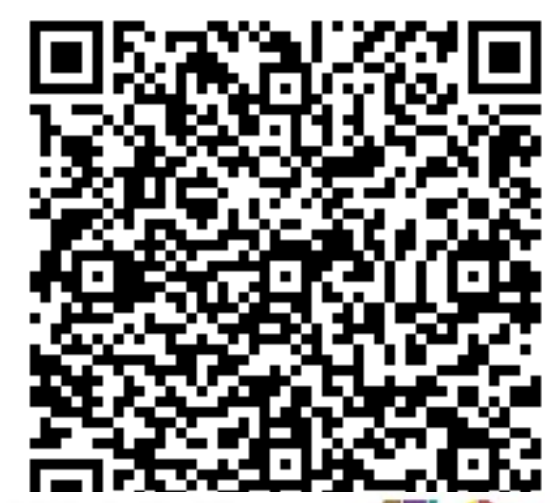

Consejo Latinoamericano de Ciencias Sociales

Conselho Latino-americano de Ciências Sociais 


\title{
“Mineirinho" de Clarice Lispector, una reflexión sobre la violencia
}

\author{
María Cristina Hernández Escobar*
}

RESUMEN: Este ensayo sobre una crónica de Clarice Lispector es una propuesta de revisar algunas ideas sobre la naturaleza de la violencia y su ejercicio, intrínsecamente vinculados con el concepto de justicia, todo ello a la luz de un texto clave de Walter Benjamin con el que parece desarrollarse un diálogo nacido de una preocupación vigente: la necesidad de entender qué es ser justos, lo que pasa por asumir que toda búsqueda de justicia conlleva algún tipo de violencia, pero que aún desconocemos casi todo sobre ese vínculo al que suelen oponerse la banalización del concepto de justicia y discursos alienantes como los propios de dos entidades autoritarias: las religiones y el Estado.

Palabras Clave: violencia, justicia, delincuente, policía.

Aвstract: This essay, about a literary text of Clarice Lispector, is a proposal to explore some ideas about the nature of violence and its accomplishment, strongly linked to another key concept: justice. This text seems to establish a dialogue with another reflection about those concepts, this one written by Walter Benjamin. Both texts, undoubtedly, were conceived from a current concern: an understanding of what being fair means. That implies the comprehension of another fact: going in search of justice touches the concept of violence. But, most of us ignore almost all about this strong link, and most of the times, instead of analysis, we hear alienating speeches from authoritative institutions, such as religions and State, that make us suffer the consequences of their banalization of the concept of justice.

KEYWORDS: violence, justice, criminal, police.

Recibido: 10 de septiembre de 2015. Aceptado: 08 de noviembre de 2015 .

L a violencia es algo consustancial a estar vivos. Nacer es violento; seguir vivos y ganarse la vida son actos de violencia extrema que entrañan el triunfo de una semilla que compite por seguir su camino en un medio hostil, ácido y laberíntico; respirar el aire cargado de muerte de las ciudades y los campos contaminados; y salir cada día o cada noche para procurarse una mínima congruencia con un sueño de progreso que pasa por

Editora de la revista Voices of México del Centro de Investigaciones sobre América del Norte de la UnAM, <hernandez_escobar@yahoo.com.mx>. 
tener un sitio dónde poner los pies sin ser expulsados de inmediato, un espacio para el disfrute y para una cierta mirada de reconocimiento.

Pero también, ese sueño de vida en un contexto violento involucra tener derecho a la disidencia, incluso a no ser "gente de provecho" - como sinónimo de generadores de riqueza-, sin por ello padecer la amenaza, la intimidación, el aplastamiento social en forma de pensamiento, palabra, obra u omisión, o todo junto encarnado en la censura social y en el aparato legal, expresión y soporte de esa forma de pensamiento marginalizante.

Sin embargo, las sociedades modernas han soslayado al individuo y lo han olvidado. Al olvidarse una comunidad - una provincia, un Estado, un sistema o una persona- que todo colectivo está compuesto por individuos - que con todo lo históricamente determinados que puedan ser son seres únicos, particulares, irreductibles- ejerce un tipo de violencia y promueve algo que quiero suponer contrario a sus expectativas: el rechazo del individuo a ese colectivo o a ese otro individuo que lo expulsa, que no se interesa por su particularidad ni por sus necesidades, entre ellas el de gozar de una existencia digna, de una intimidad y el de construirse una identidad que incluso niegue la imagen de ciudadano exitoso promovida por los medios masivos de comunicación.

Ese sentimiento de vivir el exilio en la propia casa puede tomar todas las rutas y manifestaciones imaginables y aun otras impensadas, pero siempre generará una dosis de revancha. ¿Quién quiere permanecer en la frustración?

A esa cierta toma de conciencia, más o menos estructurada la sigue la formulación de una estrategia de resarcimiento que puede presentarse bajo la forma de un acuerdo que establece un individuo consigo mismo o con otros para llegar a un fin que considera justo, empleando para ello medios que van desde las manifestaciones públicas y las huelgas hasta la batalla en tribunales; pero también, para saciar el deseo de justicia el individuo puede acudir a otras formas de expresión y movilización: el sabotaje, el vandalismo, la delincuencia, todas -éstas y aquéllas - estrategias de guerra.

El individuo movilizado, sea empleando medios legales como ilegales, ejerce siempre violencia, porque, como dije antes, violencia es todo lo que resiste y se rebela contra la inercia.

En el presente trabajo me enfocaré al uso de la violencia transgresora de las leyes de un Estado que, a su vez, ha ejercido la violencia sistemática contra sus ciudadanos o ciertos sectores sociales a los que ha convertido en marginados. 
Parte importante de la responsabilidad por este estado de cosas recae en quienes guardamos silencio por suponer que la represión es la única forma de lidiar con la violencia, porque el ser humano que la esgrime fuera de la ley, suponemos, es siempre alguien perverso y alienado, que muy probablemente lo es de nacimiento, por ambición, y que merece ser castigado sin más. Suponemos que ese otro, llamado en el discurso religioso nuestro semejante, es en realidad un desviado, culpable de sí mismo.

Ésta no es la crónica del buen ladrón muerto a manos de la policía. Para Clarice Lispector, "Mineirinho" es nuestro error, nuestro espejo, donde vemos, en silencio, lo que hemos hecho de un ser humano (Lispector, 1979: 102) al dicotomizar maniqueamente el significado de ser humano y banalizar el concepto de justicia, por acción o por omisión.

“MINEIRINHO"

"Porque ni aun el Padre juzga a nadie, sino que todo juicio se lo ha confiado al Hijo."

Juan 5:22

El $1^{\circ}$ de mayo de 1962, el asesinato en Río de Janeiro del delincuente "Mineirinho" tocó de manera especial a algunos miembros de la sociedad brasileña. Decenas de personas de los barrios marginales comparecieron en el lugar donde fue encontrado el cadáver (colocado, se diría después, tras diversos testimonios de que el bandido había sido asesinado en otro sitio). Nadie pudo acercarse, pues la policía los apartaba a todos con violencia. En general, los habitantes de las favelas se mostraban contrariados con la muerte de "Mineirinho", al que consideraban una especie de Robin Hood, aun cuando era de todos conocido su historial.

Al Instituto Médico Legal, adonde se llevó el cuerpo, también llegaron muchas personas; todas fueron revisadas e interrogadas buscando identificar entre ellas a posibles cómplices.

Antes de los hechos, un conocido suyo había declarado en prisión que "Mineirinho" sólo se entregaría muerto, y que si se había fugado de la cárcel había sido para ir tras el policía que lo había encerrado (Diário Carioca, 1962, s/p).

La prensa sensacionalista se desbocó narrando los hechos con gran detalle, tanto de la carrera delincuencial (asaltaba grandes tiendas a plena 
luz del día, por ejemplo), detallando los sucesivos operativos montados para detenerlo, sus estrategias, pero también aspectos de su vida privada, como la pasión que sentía por una mujer llamada Maria Helena y su acendrada fe religiosa: entre sus ropas se encontró una oración a San Antonio, a quien cada día encomendaba el éxito de sus "negocios".

Se empleó mucha tinta en hablar sobre el suceso desde la superficie, como un caso más del triunfo de la policía sobre un "desviado" social; no obstante, la perplejidad de la sociedad que tenía otro punto de vista de la tensión entre las transgresiones y las órdenes que recibía la policía no estaba sola.

Para ellos, que no desconocían quién era el asesinado, el hecho no podía interpretarse simplemente como un acto de justicia. Era un asunto mucho más complejo que un ajuste de cuentas. No era fácil entender que quien arriesgó su vida para ayudar a algunos de ellos hubiera sido cazado como una fiera rabiosa. Era uno de ellos, pero no todos habrían hecho lo que "Mineirinho" fue capaz de hacer. Los sentimientos contradictorios acerca de la trayectoria y motivos de personas como él son un dilema sin resolver aún hoy.

Pero no sólo los beneficiarios y admiradores se sintieron contrariados, el dilema también tocó a otras personas, una de ellas fue la escritora Clarice Lispector, quien escribió la crónica "Mineirinho" $\mathrm{y}$, al ser entrevistada en un célebre programa, varios años después del suceso y de haber escrito aquel texto, se refirió a él como

Uma coisa que eu escrevi sobre um bandido, sobre um criminoso chamado Mineirinho, que morreu com treze balas, quando uma só bastava. [...] O que me deu uma revolta enorme. Eu não me lembro muito bem, já foi há bastante tempo, qualquer coisa assim como o primeiro tiro me espanta, o segundo tiro não sei o quê, o terceiro tiro coisa... o décimo segundo me atinge, o décimo terceiro sou eu. Eu me transformei no Mineirinho massacrado pela polícia. Qualquer que tivesse sido o crime dele uma bala bastava. O resto era vontade de matar, era prepotência (entrevista con Júlio Lerner, 1977).

Si bien, parte de las vivencias de un escritor aparecen en sus textos, lo narrado no puede tomarse como un testimonio sino como una construcción metafórica donde si algún suceso de la biografía del escritor aparece lo hace transfigurado, recontextualizado y redimensionado extrayendo aquello que de significante tiene para hacer vivir al lector lo que el narra-

1 Clarice Lispector, Para não esquecer, São Paulo: Ática, 1979. Este y otros textos fueron originalmente incluidos en la primera edición de A legião estrangeira (1964), aunque la crónica se publicó por primera vez en la revista Senhor (1962). 
dor desea comunicarle, colocándolo ante sus ojos con apariencia nueva y, al mismo tiempo, con nuevas profundidades.

En el relato clariceano, aun siendo una reflexión literaria a partir de un suceso de nota roja del que no fue testigo presencial, la violencia se aborda desde un punto de vista predominantemente filosófico y plantea al lector varias preguntas, entre ellas, ¿qué diferencia existe entre la violencia del delincuente pobre y la de quien es pagado por el Estado para aniquilar el presunto origen de la violencia social? ¿A quién protege el dedo que aprieta el gatillo? ¿Quién aprieta el gatillo? ¿Quién es el otro? ¿Qué grado de responsabilidad tenemos en acontecimientos como ésos? ${ }^{2}$

No pretendo restar responsabilidad a nadie, porque de eso se trata a veces la violencia: de restar, de borrar, de obligar al individuo a desdibujarse, de construir encima de lo vivo. Mejor lo plantearé así: en este ensayo me enfocaré en el uso de la violencia que ejerce quien tiene el poder de usar un arma y cuenta con el permiso casi irrestricto para hacerlo, inserto a su vez en un entorno que de muchas formas ejerce violencia contra la ciudadanía, incluso cuando decide guardar silencio y quizá principalmente por esa decisión: la de permanecer callado dejando que se escuchen por todo los medios los discursos más autoritarios: los de las religiones y los del Estado y sus aparatos de propaganda.

Los cuestionamientos del texto de Lispector, aunque no derivan en juicios, están dirigidos a quienes desde la incomprensión del problema apuntalan sus sueños de justicia con los huesos, la carne y los anhelos de sus semejantes.

A fin de entender el concepto de violencia me he basado en el ensayo "Para una crítica de la violencia" de Walter Benjamin.

\section{LA LEY EN LOS MÁRGENES: PARA UNA DEFINICIÓN DE LA VIOLENCIA}

De acuerdo con Walter Benjamin, "una causa eficiente ${ }^{3}$ se convierte en violencia, en el sentido exacto de la palabra, sólo cuando incide en relaciones morales. La esfera de tales relaciones es definida por los conceptos de

\footnotetext{
2 Predominantemente filosófico porque la narradora comienza recordando el quinto mandamiento bíblico de no matar al prójimo, aunque contextualizándolo en su realidad de persona con libre albedrío que analiza con cierta ironía los motivos para no transgredirlo, como veremos más adelante.

3 Causa eficiente es toda aquella acción que origina otra de manera lógica, inexorable, como cuando alguien abre la llave del agua y ésta sale.
} 
derecho y justicia" (Benjamin, 2007: 113). El problema está en determinar cuándo es legítima la violencia y en saber a ciencia cierta que cuando se la ejerce se está acudiendo a la única vía posible para hacer justicia. Mejor aún: si verdaderamente se está ejerciendo justicia.

La teoría positiva del derecho, señala Benjamin, distingue entre los diversos géneros de violencia, "una históricamente reconocida, es decir, la violencia sancionada como poder, y la violencia no sancionada" (Benjamin, 2007: 115). Esta última es la relevante para el presente análisis, pues se trata de la ejercida por los implicados en el suceso narrado, personajes o personas situados en la periferia de esa legalidad fundada por una elite socioeconómica y a la que oponen, en el caso de lo contado en "Mineirinho", el asesinato como respuesta unívoca, sólo porque puede ejercerse y es "legal", a una situación estructural que demanda la atención de varias necesidades, pero, ante todo, una reflexión seria y sensible sobre el ser humano.

El derecho considera la violencia en manos de la persona aislada como un riesgo o una amenaza de perturbación para el ordenamiento jurídico; no obstante, como sabemos, el interés del Estado por monopolizar la violencia no radica en salvaguardar un orden con fines jurídicos sino en salvaguardar al derecho mismo como reflejo de un orden asumido como destino (Benjamin, 2007: 117), como el mejor proyecto social posible, donde el poder de decidir sobre la vida y la muerte de los ciudadanos recae en unos cuantos, de tal suerte que quien rompe las reglas, sea por una causa revolucionaria o por un deseo de resarcimiento individual legítimo, es quien empuña y dispara el arma que le impedirá perturbar el sueño de quienes se identifican con la ley creada y preservada por ese Estado.

Según lo publicado en una de las tantas notas sobre el asesinato de "Mineirinho", él se procuró su propia muerte con cada acto transgresor:

Não foi a justiça quem decretou a morte do mais temível assaltante do Rio de Janeiro, conhecido pela alcunha de "Mineirinho". Ele próprio a procurou, desafiando a tranqüilidade pública e um aparelhamento policial cujas metralhadoras sabia não lhe dariam trégua. Carregando 104 anos de prisão, o facínora ainda brincou pelas ruas e favelas da cidade durante dias, assaltando e baleando - que estas eram sua razão de viver (Corréio da Manhã, 1962, s/p).

En la figura del bandido se proyectan los sueños de empoderamiento de un individuo o de una mayoría desarticulada que de manera explícita o silenciosa repudia las relaciones de poder resguardadas por el aparato le- 
gal vigente. ${ }^{4}$ El Estado teme que la moral del delincuente sea tan diferente de la suya que resulte creadora, ella misma, de derecho; que introduzca en el escenario social nuevas reglas de consecución de la justicia o al menos consiga atacar al sistema con sus propios medios, parodiándolos y/o usándolos para su anhelo de resarcimiento. ${ }^{5}$

Sin embargo, en el marco del Estado moderno aparece un actor que guarda una relación ambigua con el derecho: la policía,

un poder con fines jurídicos [...], pero también con la posibilidad de establecer para sí misma, dentro de vastos límites, tales fines [...]. El aspecto ignominioso de esta autoridad -que es advertido por pocos sólo porque sus atribuciones en raros casos justifican las intervenciones más brutales, pero pueden operar con tanta mayor ceguera en los sectores más indefensos y contra las personas sagaces a las que no protegen las leyes del Estado-consiste en que en ella [en la policía] se ha suprimido la división entre violencia que funda [nuevas reglas] y violencia que conserva la ley (Benjamin, 2007: 123).

La policía interviene "en nombre de la seguridad" (Benjamin, 2007: 124) en innumerables casos en los que la situación jurídica del hecho o de los implicados no resulta clara, y lo hace como una vejación brutal, sin relación con fines jurídicos, cuando el Estado "se siente incapaz de garantizar" por medios legales los fines que persigue a cualquier costo (123-124). En contraste con el derecho, la institución policial "no se funda en nada sustancial. Su violencia carece de forma, así como su irrupción inconcebible, generalizada y monstruosa, en la vida del Estado civilizado" (124).

Según veremos en el texto analizado, aunque la autora no hace de su análisis un vehículo para la piedad ni mucho menos una idealización del delincuente, lo que por principio la colocaría fuera de los hechos sobre los que escribe y al margen de sus propias palabras, la policía aparece como lo que es: un perpetuador del círculo de la violencia. Un enemigo que come de nuestra mano.

En opinión de un ex jefe de policía brasileño, entrevistado para elaborar el documental Noticias de una guerra personal, material adicional

\footnotetext{
4 Enfatizo desarticulada por oposición a los colectivos conscientes y organizados conocidos como sociedad civil, que suelen emplear otros medios de hacer justicia.

5 En este sentido, el Estado burgués históricamente se ha empeñado en identificar el acto revolucionario con el delincuencial, lo que le ha resultado muy productivo, por ejemplo, al promover la animadversión e incluso la criminalización de las huelgas, de las manifestaciones ciudadanas y otras formas de resistencia civil.
} 
incluido en la versión cinematográfica de la novela Cidade de Deus, la policía fue creada por el Estado para salvaguardarlo, y fue concebida para que éste ejerciera a través de aquélla todos los recursos de que fuera capaz, incluyendo la violencia y la corrupción, ${ }^{6}$ estableciendo con ello, dentro de los márgenes del aparato legal y fuera de él, pero contando con su silencio, sus propias reglas.

En opinión del funcionario gubernamental, la propia sociedad (al menos la brasileña, que es a la que él aludía) prefiere una policía corruptible por ser más soportable y manejable que una súper policía erigida como una súper moral vigilante que sancionara o llevara presos a los civiles o a miembros de su propio cuerpo que cometieran la menor infracción, sin dar espacio para ningún tipo de "negociación".

Toda violencia es, como medio, poder que funda o conserva el derecho, pero si no aspira a ninguno de estos atributos, la violencia renuncia por sí misma a toda validación.

Todo el problema entre el derecho y el ciudadano radica, señala Walter Benjamin, en que surge de una moral equívoca que ocasionalmente hace que nos planteemos la pregunta de si no existirán otros medios que no sean los violentos para armonizar intereses humanos en conflicto (2007: 124) o para reconocer derecho de existencia a las necesidades materiales (las relativas a la subsistencia, a la salud, por ejemplo), intelectuales (acceso a la educación, a la cultura) y emocionales, a las pasiones y flaquezas que eventualmente pueden empujar al delito.

A medios legales e ilegales de toda índole - continúa Benjamin-, que son siempre todos violentos, es lícito por lo tanto oponer, como puros, los medios no violentos. Delicadeza, simpatía, amor a la paz, confianza y todo lo que se podría añadir constituyen su fundamento subjetivo, pero su manifestación objetiva se halla determinada por la ley, que establece que los medios "puros" no son nunca medios de solución inmediata, sino siempre de soluciones mediatas. Un ejemplo lo constituye tal vez la conversación considerada como técnica de entendimiento civil (Benjamin, 2007: 126).

La reflexión presente en "Mineirinho", de Clarice Lispector, tiene mucho que ver con esta otra vía que propone Benjamin.

La creación de derecho es creación de poder.

6 Noticias de una guerra personal, documental filmado en Río de Janeiro entre 1997 y 1998, dirigido por Fernando Meirelles, y que incluye opiniones del periodista y escritor Paulo Lins. Está incluido en el DVD de la película Ciudad de Dios, adaptación de la novela homónima de Lins. 
En Reflexiones sobre la violencia, Georges Sorel plantea la hipótesis de que en los comienzos todo derecho ha sido privilegio del rey o de los grandes, en una palabra, de los poderosos. Y eso seguirá siendo mutatis mutandis, mientras subsista (Referido por Benjamin, 2007: 133). Por desgracia, este poder equiparable con el de un rey o con el de un dios que se adjudica el Estado al momento de juzgar la conducta de un individuo o de un colectivo transgresor ha trabajado sus anclajes en la conciencia de esa misma sociedad que en buena medida se ve representada en la actitud desafiante de los delincuentes, pero que de la misma forma no dudan en condenar sus acciones sin analizar la posible legitimidad de sus fines ni la exploración de otras formas de ser justos sin reprimir y sin aumentar el repertorio de argumentos para la misantropía.

“MINEIRINHO”: LO PELIGROSO ES ESTAR VIVO

É, suponho que é em mim, como um dos representantes do nós, que devo procurar por que está doendo a morte de um facínora.

Esta breve crónica así iniciada, crónica de la perplejidad, ofrece otra perspectiva del fenómeno de la violencia: la del espectador situado circunstancialmente del lado de los jueces, nosotros, los que seguimos vivos.

Pero, ¿quién era "Mineirinho"?

José Miranda Rosa, "Mineirinho", nacido en Minas Gerais, fue uno de los bandidos más buscados por la policía carioca en los años sesenta debido a sus recurrentes y peligrosas infracciones, como numerosos asaltos a tiendas a plena luz del día, atentados contra la policía militar de Río de Janeiro - no está de más recordar que esto lo perpetró en plena dictadura- y tres fugas, dos de una cárcel y una del Manicômio Judiciário donde estaba condenado a cumplir una condena de 104 años. Desde que se fugó de allí, se organizaron meticulosamente varios mecanismos para atraparlo, lo que se dificultaba de manera especial a las autoridades debido a que "Mineirinho" conocía muy bien las laberínticas favelas de la ciudad y ocasionalmente contaba con protección de algunos de sus habitantes, quienes le brindaban asilo por considerarlo, como mencioné, una especie de Robin Hood.

Hasta que un día uno de los grupos policiacos, integrado por 300 elementos, dio con su paradero y literalmente lo cazó: aun cuando un solo balazo acabó con su única vida, el cuerpo de "Mineirinho" recibió doce tiros más. 
La narradora del texto de la brasileña Clarice Lispector (Ucrania, 1920Río de Janeiro, 1977) inicia su reflexión sobre el asesinato del bandido buscando una cierta comprensión ante la incapacidad para explicarse la revuelta, la división interior que se experimenta frente a la paradójica aplicación de la violencia como instrumento para el mantenimiento de un orden y de una paz que no descansan, pues se tambalean con los pies mal afincados en una justicia basada en la aniquilación del error, no en evitar que se cometa. Un error propio, además.

Para intentar responder a esa inicial imposibilidad de saber qué siente exactamente ante el asesinato del delincuente, la narradora interroga a su cocinera, quien se ha enterado a través de los medios de la vida y muerte del joven: "Perguntei a minha cozinheira o que pensava sobre o assunto. Vi no seu rosto a pequenha convulsão de um conflito, o mal-estar de não entender o que se sente, o de precisar trair sensações por não saber harmonizá-las" (Lispector, 1979: 101).

En la forma de responder de la mujer, en el destello de rabia que se trasluce en sus palabras, la narradora intuye cuál es su sitio, desde el cual le corresponde hacer las preguntas. La molestia de la cocinera ubica a la narradora entre quienes tendrían que sentirse vengados con la muerte de José Miranda Rosa.

La trabajadora acude al argumento mediático para calmar la propia desazón ante la pregunta, a lo que todo mundo sabe: "Mineirinho" era un delincuente, pero la inmensa misericordia de la justicia de Dios le había otorgado la salvación.

El texto es un desarrollo predominantemente filosófico, aunque la narradora comienza recordando el quinto mandamiento bíblico, contextualizándolo en su realidad de persona con libre albedrío que analiza con cierta ironía los motivos para no transgredirlo: no matar para no ser el posible blanco de una reacción de igual (o mayor) intensidad; no matar para no cargar con la culpa.

El mandamiento, parte de su educación familiar y social, queda expuesto como una trampa que promueve el disimulo y el distanciamiento ante el deber de tomar una postura frente a la compleja naturaleza humana, frente a la vida y muerte de quien ha roto el contrato social, uno creado y sustentado en el derecho y mantenido por el Estado, pero también frente a unos hechos y una reacción social que la ponen por completo en entredicho, a ella, como un individuo, comenzando por el reconocimiento 
de haber sentido alivio y seguridad al escuchar los dos primeros disparos, lo que a medida que enumera las detonaciones va abriendo el piso bajo sus pies e inaugura, desde otros parámetros -éticos, ya no morales-, el cuestionamiento sobre los motivos de quien dispara y sobre la identidad de quien recibe las balas.

Inicia, pese a su educación religiosa y todo el discurso social que refleja y difumina sus enseñanzas, la reconfiguración de un ser humano a partir de la palabra que intenta ser propia.

El discurso religioso institucional impone los recursos del miedo y la culpa como mecanismos de control social, cumple una función ancilar, lo sabemos, sobre todo a partir del concilio de Nicea que consolida al imperio romano, pues miedo al prójimo no es respeto y culpa no es responsabilidad asumida.

Ahora, el simple mandamiento no permite deducir, sólo interpretar, que habrá un juicio sobre la acción (Benjamin, 2007: 135), tampoco una consecuencia, por tanto no ha lugar para pensar que la venganza sobre alguien que ha matado es una reacción esperada, como acto de justicia divina, pero tampoco de justicia humana. ¿Desde dónde partir para resolver el dilema ético, si esto es posible?

\section{“ESSA JUSTIÇA QUE VELA MEU SONO, EU A REPUDIO, HUMILHADA POR PRECISSAR DELA"}

La justicia es el criterio de los fines que pueden hallarse fundados en motivos legítimos e ilegítimos, ${ }^{7}$ lo que hará que se hable de fines justos o injustos, respectivamente; que se persigan por medios legales (previstos en el derecho) o ilegales (sancionados o simplemente no contemplados hasta el momento en la legislación).

Para Benjamin, la noción de justicia es inseparable del concepto de violencia, y para ello, en su ensayo, analiza todos los aspectos que la definen, los contextos en que se despliega y los modos en que se ejerce para entender por qué justicia y violencia van unidas, por qué entre los individuos como entre los colectivos el respeto al derecho ajeno, ni siquiera la

7 Sobre la legitimidad, Bobbio dice que en el lenguaje ordinario, el término legitimidad tiene dos significados, uno genérico y uno específico, ligado a la política, y su referente más frecuente es el Estado. En el significado genérico es casi sinónimo de justicia y razonabilidad, así, se habla de legitimidad de una decisión, de una actitud, etcétera. A éste aludo (Bobbio, 2006). 
armonización de intereses, jamás ha sido una tarea sencilla desde ningún punto de vista, pese a que el interés por debatir sobre el derecho y la elaboración de códigos civiles y otras formas de regular las relaciones humanas son afanes tan antiguos.

La reflexión de la narradora se desarrolla, como mencioné, en forma de una gradual toma de conciencia detonada con cada uno de los trece disparos sobre el cuerpo del joven. Si al escuchar los primeros dos la sensación fue de "alívio e segurança", a partir del tercero la conciencia recorre una pendiente vertiginosa y revienta la barrera de la otredad entendida como sinónimo de enajenación, por lo que la narradora concluye "O décimo terceiro tiro me assasina - porque eu sou o outro. Porque eu quero ser o outro" (Lispector, 1979: 101). Con lo que en verdad detona su revolución particular, su búsqueda de justicia.

La justicia que decide matar antes que ser justa y dar un espacio al análisis sobre la responsabilidad que cada parte tiene en un hecho no puede ser algo representativo ni protector. Quien duerme bajo su manto lo hace intranquilo y con miedo o desde la complicidad en la ejecución de una falsa justicia que otorga el derecho de ira y resarcimiento a quien puede pagarlo.

La narradora, para estructurar su pensamiento, parte de la imagen más cercana: ella misma dentro de su casa y, para que su casa, metáfora de su mente, funcione, dice, "exijo de mim como primeiro dever que eu seja sonsa, que eu não exerça a minha revolta e o meu amor, guardados. Se eu não for sonsa, minha casa estremece. [...]" (Lispector, 1979: 102).

Qué clase de casa es ésa cuyas paredes se mantienen erguidas gracias al cemento y las varillas del disimulo ciudadano y de una legalidad basada en la idea de que el delincuente es un desviado que merece castigarse sin averiguar las causas que lo llevaron a esa situación.

$¿$ De verdad el delincuente es un otro? ¿Su territorio es la otredad de la que estamos salvados nosotros y nuestra estirpe porque hay algo distinto en nuestra genética, en nuestro temperamento? Hacerse esa pregunta de manera auténtica deconstruye: "Em Mineirinho se rebentou o meu modo de viver", dice la narradora (Lispector, 1979: 102).

\section{“MINEIRINHO" ANTE EL ESPEJO}

La supuesta igualdad ante la ley otorga a unos el derecho de expresión y a otros los anula. Qué clase de individuo puede dormir con tranquilidad sabiendo lo que sucede, que debajo de esa casa mal edificada queda un 
terreno a partir del cual podría construirse algo distinto y a nadie parece importarle. Cómo quedarse en paz habiendo desorganizado, a lo largo del tiempo de los trece disparos, el orden aceptado por una comunidad de individuos que no se han mirado a sí mismos con la suficiente atención, que desvían los ojos del espejo en cuanto lo que perciben los desconcierta.

Para la narradora, "Mineirinho" no es un desviado. El mundo donde se forjó no es uno de malos y buenos, como si habláramos de fichas blancas y negras: ese algo poderoso que lo llevó a robar y matar es la misma materia que enciende el corazón de quien se empeña en mover montañas para cambiarlo todo si es necesario o del que escribe el poema más sublime. Ese algo que al ser pisado provoca una reacción que, en opinión de algunos, puede exceder al volumen del daño infligido. Pero ¿qué sabemos de cómo vive el abuso otro agraviado?

El delincuente está forjado del mismo barro oscuro y de la misma agua que sus jueces, pero ha sido menos afortunado. "Mineirinho" robó y mató por todos los que sintiendo ese deseo no lo hicieron porque quizá tuvieron la opción de darse la vuelta hacia una vida distinta. La violencia de "Mineirinho", dice el narrador, es inocente "não nas conseqüências, mas em si inocente como a de um filho de quem o pai não tomou conta" (Lispector, 1979: 102).

No por sus consecuencias sino por sus orígenes: es el error que todos hemos cometido al permanecer callados cuando a él le fallaba el habla y se desesperaba en nuestro lugar; al desviarnos de nuestra responsabilidad de construir una casa distinta como un fruto digno de ese terreno sobre el cual se levanta ese edificio.

Cuando una bala - en ese caso trece- atraviesa el cuerpo de una persona, delincuente o no, en un contexto en el que una violencia ensordece los orígenes y motivos de otra violencia al colocar el Estado su derecho por encima de cualquier otro sin que medie la voluntad de reconocimiento ni de refundación social, "está sendo morto um inocente" y quien empuña esa arma y comete ese "fusilamiento" no nos protege "nem querendo eliminar o criminoso, ele está cometendo o seu crime particular, um longamente guardado" (de todos los entrecomillados, Lispector, 1979: 103), amparado en una justicia que entrega la maldad de un hombre a la de otro, olvidando que todos somos peligrosos, en especial los que tras desordenar ese orden tan amado por algunos nos mantenemos callados permitiendo que nuestro terreno se envilezca con toda clase de mentiras sobre la naturaleza humana. 
"Mineirinho" no es una apología de la delincuencia, como en cambio sí lo es la postura irreflexiva de quien cree en la maldad o la bondad como cualidades intrínsecas, no como construcciones perfectamente humanas. “Todo o que nele foi violencia - afirma- é em nós furtivo, e um evita o olhar do outro para não corrermos o risco de nos entendermos. Para que a casa não estremeça" (Lispector, 1979: 103). Mirar seriamente implica dejarse estremecer, destruirse de principio a fin, si es necesario, para entender. Si no se entiende, se trabaja en favor de la violencia conservadora. Se es responsable directo de ella. El propio derecho nos dice que el desconocimiento no exime de responsabilidad. Una concepción de justicia que no se mira a sí misma es tan peligrosa como absurda.

Luego de tantos siglos de estudios y debates sobre la naturaleza humana, sobre el derecho, sus contenidos y sus límites, ya no se puede justificar el proceder de las personas ni de los colectivos ni de las instituciones estatales como mandato de la voluntad divina; no obstante, aún seguimos inmersos en un mundo cuyas dinámicas se basan en las más groseras manifestaciones de la opresión de género, económica, sexual y emocional como si todos esos debates y estudios mencionados nada tuvieran que ver con la realidad.

Novelistas como Clarice Lispector no son ajenos ni refractarios a esa vivencia, pero la diferencia entre hacer una nota periodística y escribir un poema - en el sentido que dio Octavio Paz a ese término- es abismal. Ambos géneros nacen de un compromiso con la verdad, pero tienen distintos instrumentos para descubrirla y decirla.

En el caso de la crónica literaria, aun cuando esté emparentada con el género periodístico, la crítica emplea recursos mucho menos evidentes que en el periodismo, pero no por ello es menos profunda, sino, todo lo contrario, pues, como expresa Huidobro en su "Arte poética" (1916), al escritor no corresponde cantar la rosa, sino hacerla florecer en el poema. Al escritor no le corresponde reportar los hechos y enjuiciarlos, sino permitirnos sentir sus repercusiones en nosotros como humanos.

El poema, es decir, toda obra literaria tiene a la metáfora para hacer florecer la rosa, entendiendo por metáfora, de manera general, un ejercicio heurístico, de redescripción de la realidad, de aportación de información novedosa sobre algo ampliamente conocido. De la misma manera en que un escritor elige una historia personal y un nombre para darse a conocer, también encuentra una manera propia de hablar sobre sus preocupaciones y obsesiones. 
Formular conclusiones definitivas sobre los hechos - los históricos, los sociales- pertenece al terreno del libro de texto o de la nota periodística. Escritoras como Lispector tampoco expresan su crítica en forma de juicios éticos. No corresponde al escritor dictar línea moral. En este sentido, fue duramente criticada por no adoptar una postura abiertamente identificable con algún bando u otro en tiempos de la dictadura; no obstante, esta acusación nace de una visión demasiado estrecha del significado de tomar partido. Ella, interesada seriamente por las reacciones que su escritura y su actuar despiertan, declara en una carta a su amiga Olga Borelli, quien le pregunta por qué escribe:

Cursé la facultad de Derecho porque deseaba reformar el mundo, no me considero una escritora ni participante ni comprometida en movimientos de cualquier especie. Tengo una conciencia crítica suficientemente formada para reconocer los abusos y las explotaciones de los que yo y la mayoría de mis colegas somos víctimas (Battella, 2007: 480).

Más adelante, en la misma carta, expresa que la gente sólo puede hacer bien las cosas que ama realmente, y que sus libros

no se preocupan mucho por los hechos en sí porque, para mí, lo importante no son los hechos en sí sino las repercusiones en el individuo. Eso es lo que realmente importa. Y es lo que yo hago. Pienso que, sobre ese aspecto, también hago libros comprometidos con el hombre y su realidad, porque la realidad no es un fenómeno puramente externo (Battella, 2007: 481).

Algo que esta crónica muestra, más allá de su visión de la violencia, es que ésta nace y se nutre de la incomprensión, de los prejuicios que impiden mirar las causas eficientes de la rabia de quien dispara cuando fallan los canales de comunicación, algo frecuente no sólo en las ciudades latinoamericanas acorraladas por la dependencia en muchos sentidos, sino en todos los espacios donde no haya interés por despojarse de ese supuesto esquema que separa a las personas en buenas y malas, en decentes y peligrosas.

Algo con lo que la filosofía y las artes han contribuido de manera extraordinaria para la destrucción de ese mundo maniqueo es justamente con esa mirada escudriñadora que en un esfuerzo de responsabilidad social han puesto sobre el alma humana, y que a través de textos como el analizado aquí permiten concluir que mientras no nos asumamos como seres complejos $-\mathrm{y}$ por tanto frágiles y peligrosos mientras respiremos, y aun después - no podremos construir la casa, la sociedad, el sistema legal que necesitamos para merecer el suelo sobre el que nos afincamos. 
Por eso esta historia nos interpela y a algunos nos deja como a la cocinera y al narrador, tratando de entender y de vencer la perplejidad, la sordera, no obstante el ruido de las balas.

\section{BIBLIOGRAFÍA}

BATTELlA GOTLIB, N. (2007); Clarice: una vida que se cuenta. Biografía literaria de Clarice Lispector, trad. de Álvaro Abós. Buenos Aires: Adriana Hidalgo Editora.

BENJAMIN, W. (2007); "Para una crítica de la violencia", en Conceptos de filosfía de la historia, trad. de H. A. Murena y D. J. Vogelmann. Buenos Aires: Terramar Ediciones, pp. 113-139.

BOBBIO, N. (2006); Diccionario de política. Buenos Aires: Editorial del Cardo, Biblioteca Virtual Universal. www.biblioteca.org.ar/libros/131821.pdf.

LISPECTOR, C. (1979); “Mineirinho”, en Para não esquecer. São Paulo: Ática, pp. 101-103.

\section{MATERIAL AUDIOVISUAL}

Noticias de una guerra personal, documental filmado en Río de Janeiro entre 1997 y 1998, dirigido por Fernando Meirelles, y que incluye opiniones del periodista y escritor Paulo Lins. Está incluido en el DvD de la película Ciudad de Dios, adaptación de la novela homónima de Lins.

Entrevista de Júlio Lerner con Clarice Lispector para TV Cultura, transmitida en 1977. Dicha entrevista es célebre no sólo por todo lo que dijo en ella sobre sí y sobre su obra, sino porque, a petición de la escritora, se difundió post mortem. https://www.youtube.com/watch? $=$ ohHP1l2EvnU.

\section{PRENSA}

Correio da Manhã , $1^{\circ}$ de mayo de 1962, s/p, en "O Rio de Janeiro através dos jornais". www1.uol.com.br/rionosjornais/rj45.htm.

Diário Carioca, $1^{\circ}$ de mayo de 1962, s/p, en “O Rio de Janeiro através dos jornais”. www1.uol.com.br/rionosjornais/rj45.htm. 